\title{
THE SUBLITTORAL FAUNA OF TWO SANDY BAYS ON THE ISLE OF CUMBRAE, FIRTH OF CLYDE
}

\author{
By R. B. Clark \\ Department of Zoology, Glasgow University \\ and A. Milne \\ Department of Agriculture, King's College, Newcastle on Tyne
}

(Text-figs. I and 2)

\section{INTRODUCTION}

There is a considerable literature on the ecology of intertidal animals and a growing one on the sublittoral fauna. Largely because of the difficulty of taking samples in very shallow water, little attention has been paid to the continuation of the intertidal zonation below the low-water mark. Although incomplete in some respects, the results of the present survey are published, partly to help bridge the gap between studies of sublittoral and intertidal faunas, partly because it is unlikely that this survey will ever be completed and partly because the intertidal fauna of one of the bays is particularly well known. The work was begun in 1938 by one of the authors (A.M.) but was discontinued at the outbreak of the late war. Since 1949 further collections have been made and the identity of most of the species taken in the earlier sampling has been checked. The collections of animals and a full account of the results have been deposited in the Marine Laboratory at Millport.

\section{METHODS}

None of the larger and more reliable bottom samplers can be operated from the small boat that must be used in shallow water. All samples in the quantitative survey were taken by the Robertson mud bucket, that is, a cylindrical bucket about 15 in. long and 8 in. in diameter with a sharpened edge. The bucket lies on its side and, when hauled, cuts downwards at an angle until filled. The volume of the material taken in a sample is about $8000 \mathrm{ml}$. This instrument has several advantages; it can be used from a rowing boat (with or without an out-board motor) in very shallow water, it fills rapidly even when the substratum is hard sand and, so far as one can see on a calm bright day, the bucket fills in the same way at all depths within the limits of visibility, irrespective of the angle of the hauling rope. One disadvantage is that it collects a disproportionately large number of animals living just below the 
surface of the sand, though this drawback it shares with the majority of bottom samplers in current use. Another disadvantage is that densities of populations cannot be expressed in absolute terms, i.e. numbers per unit area of sea bed. However, the Robertson bucket does give reasonably accurate estimates of relative densities and that is sufficient for the purposes of this paper.

Each sample was washed through a $2 \mathrm{~mm}$ sieve. From the residue the larger animals were picked out by hand, while a binocular microscope was used to search for smaller animals. Formalin was added to dislodge small animals, such as Siphonoecetes which live in crevices of stones and shells.

A series of ten samples was taken at each of seven stations at depths of $I$, $3,5,6 \frac{1}{2}, 10 \frac{1}{2}, 20$ and $27 \mathrm{~m}$ below low water (mean ordinary tide) in each of the two bays. Kames Bay was studied in late autumn and winter (between November 1938 and January 1939) and White Bay in late spring and summer (between May and August 1939). This difference in sampling time may affect comparisons of densities for the two bays in the case of species whose young appear on the sea bottom in the early part of the year. It is impossible to say which bay is favoured in this respect: on the one hand, some young will not be large enough for retention on the sieve by May-August; on the other hand, some young will have succumbed from natural causes before NovemberJanuary. In the preliminary work of $1938-39$, the prime concern was to establish the composition of the fauna in the two bays and gain facility in identification. For the comparison proper, it was intended to repeat the sampling simultaneously in the two bays at the rate of 30-50 buckets per station in the winter of 1939-40. Unfortunately the Second World War frustrated this intention.

In order to collect animals living on, or just above, the surface of the substratum, samples were taken by a $4 \mathrm{ft}$. 9 in. beam trawl with a $\frac{1}{4}$ in. mesh lined with $2 \mathrm{~mm}$ stramin. The trawl was hauled for a standard distance at each station in calm weather.

\section{Conditions In the Two Bays}

The two bays studied were Kames Bay, facing south-east and sheltered from all other directions, and White Bay, facing north-north-east and relatively exposed to the east and north. The Isle of Cumbrae is exposed to the open sea to the south but is sheltered to some extent by neighbouring islands and the mainland in other directions. In Kames Bay the substratum consists of sand grading into fine mud at the deeper stations with only a slight admixture $\mathrm{o}$ stones, while White Bay is consistently coarser with a much higher proportio! of stones and shells at each station. One peculiar feature of Kames Bay is th large amount of vegetable debris, consisting of fragments of algae and lar plants, which lies on the bottom and is washed backwards and forwards wi the tide. Although a certain amount of this debris is found at all stations, it most plentiful at the three shallowest stations. Some idea of the movem 
of this debris can be gathered from the volume of debris retained by a stramin covered trawl dragged over the sea bed for a standard distance at each of the three inshore stations:

\begin{tabular}{|c|c|c|}
\hline Station & I & 2 \\
\hline Low water, I5 March, 3 p.m. & 27 & 4 \\
\hline High water, I6 March, Io a.m. & 4 & 2 \\
\hline
\end{tabular}

At high water the bulk of the debris is over the intertidal region of the shore. The debris carries its own fauna, particularly of crustaceans, which does not figure in the bottom samples, but must nevertheless play an important role in the economy of the infauna both in competing for and providing food.

There is also a considerable volume of debris in deeper water around station 7 and possibly extending beyond it. It is of a different character from the loose debris washed backwards and forwards by the tide in that it forms the permanent superficial layer of the substratum. Usually it is partially decomposed. The volume of debris collected by the trawl at high tide when most of the movable debris is above station I and in the intertidal zone is given below.

$\begin{array}{cccccccc}\text { Station } \ldots . . . & \text { I } & 2 & 3 & 4 & 5 & 6 & 7 \\ \text { Volume of debris } & \text { I43 } & 8 & 25 & 4 & 80 & 300 & 15,000-20,000\end{array}$

\section{The Fauna of Kames Bay}

The collections made in Kames Bay supplement and extend those made by Elmhirst (I93I), Stephen (1928, I929, I930) and Watkin (1942), who, between them, have described in considerable detail the zonation of animals in the intertidal part of the bay. The lowest station of Stephen (I928) corresponds approximately with the highest station in the present survey. Elmhirst (I93I) also studied the zonation of the Crustacea in the upper part of the sublittoral zone. The position of the stations is illustrated in Fig. I.

\section{Polychaeta}

The distribution of the more common polychaetes is given in Table I. On comparison with the data given by the earlier authors for the intertidal zonation, it will be seen that in no case does a species occur in large numbers both above and below the low-water mark. This discontinuity is not found in the other groups. Nephthys hombergii is numerous sublittorally and indeed is common in muddy deposits at all but the greatest depths throughout the Firth of Clyde. Yet although it appears in moderate numbers in the intertidal zone of other parts of the Clyde (Stephen, 1928), it does not do so in Kames Bay (Stephen, I930; Watkin, 1942). According to these authors, Nephthys caeca is common in Kames Bay down to low tide level but it has not been recorded at all from the sublittoral of this bay. Spio filicornis and Phyllodoce 
maculata are common at station I, very rare below that, and absent altogether above low tide level. $P$. groenlandica replaces $P$. maculata above low-water mark, but it is not nearly as common. Most species which appear to reach a

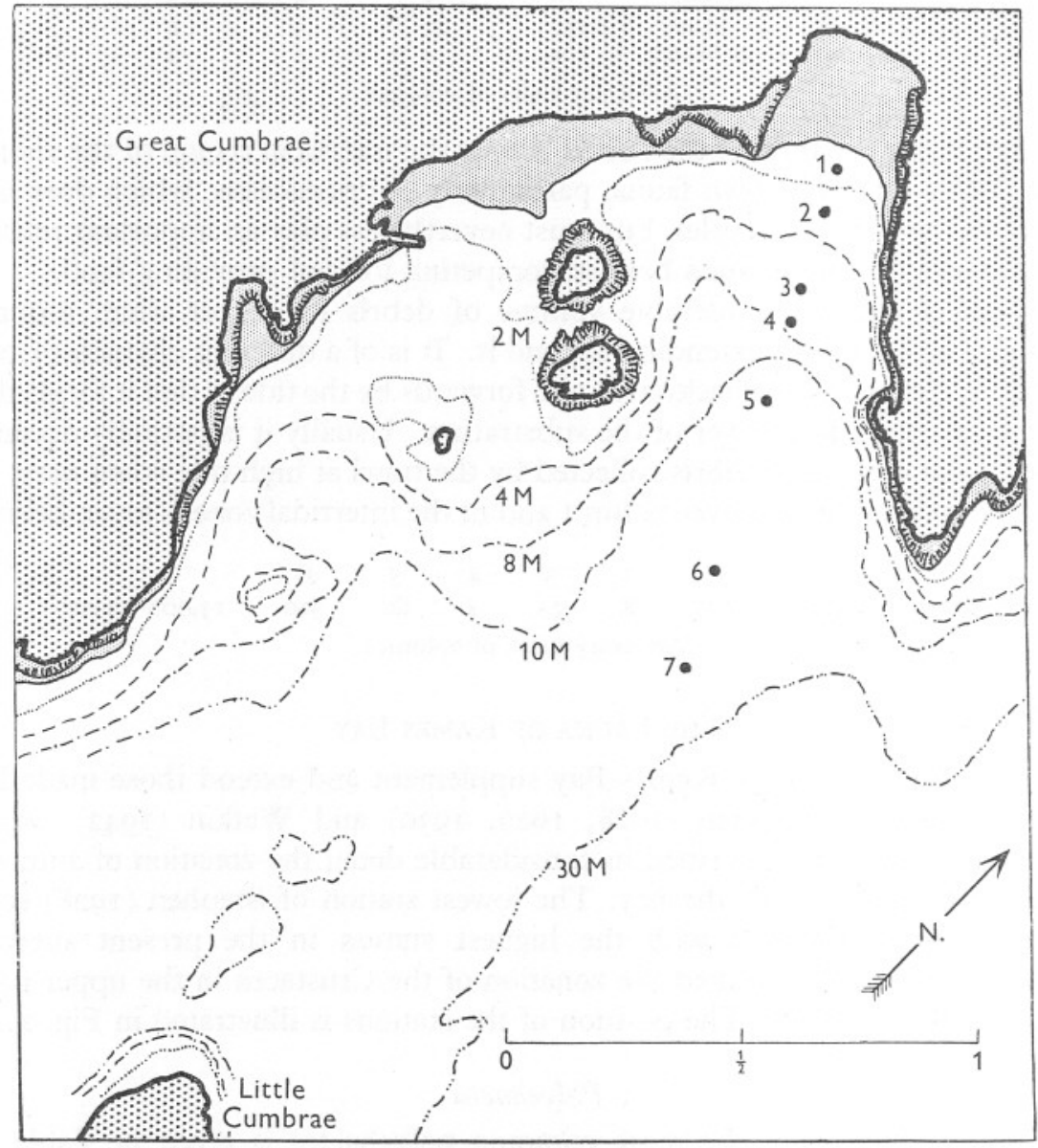

Fig. I. Kames Bay, Isle of Cumbrae, showing the position of the stations at which samples were collected.

maximum density at station 7 are, of course, more numerous still in deeper water, e.g. Scalibregma inflatum, Notomastus latericeus, Lumbrinereis hibernica, Lipobranchius jeffreysii and Glycera rouxii. The last three species are well represented in muddy deposits at almost any depth throughout the Clyde Sea area. By contrast, Melinna palmata appears suddenly and in very large numbers at station 7 and seems to occupy a narrow belt at a depth of about $30 \mathrm{~m}$ in several sandy bays in the area. 


\section{Amphipoda}

Elmhirst (I93I) has studied the distribution of crustaceans in Kames Bay from the high-water mark to a depth of $6 \mathrm{~m}$ below low water, spring tide. The present survey therefore overlaps Elmhirst's. In the overlapping region it confirms him, and his picture of zonation can now be extended to a depth

Table I. Distribution of Polychaetes in Kames Bay

\begin{tabular}{|c|c|c|c|c|c|c|c|}
\hline Station & I & 2 & 3 & 4 & 5 & 6 & 7 \\
\hline Nephthys hombergii & 92 & 85 & 42 & I9 & 43 & $3 I$ & 45 \\
\hline Spio filicornis & 70 & - & 2 & - & 2 & - & - \\
\hline Phyllodoce maculata & 23 & - & 一 & I & I & 一 & - \\
\hline Sigalion mathildae & 2 & 37 & 4I & 73 & 29 & - & - \\
\hline Owenia fusiformis & 一 & 一 & 9 & 88 & 89 & 79 & II 7 \\
\hline Sthenelais limicola & - & 2 & I & 7 & 2 & I & - \\
\hline Goniada maculata & - & - & - & 2 & - & 82 & $7 \mathrm{I}$ \\
\hline Stylarioides plumosa & - & - & 一 & - & - & I5 & 5 \\
\hline Platynereis dumerilii & 一 & - & 一 & 一 & I & 37 & 4 \\
\hline Scalibregma inflatum & - & - & 二 & $\overline{12}$ & - & $\begin{array}{r}19 \\
245\end{array}$ & 17 \\
\hline $\begin{array}{l}\text { Maldanidae } \\
\text { Glycera rouxii }\end{array}$ & 二 & - & 二 & 13 & $\begin{array}{l}7 \\
\mathrm{I}\end{array}$ & $\begin{array}{r}245 \\
12\end{array}$ & $\begin{array}{c}2-400 \\
25\end{array}$ \\
\hline Lumbrinereis hibernica & - & - & - & - & - & 15 & 20 \\
\hline Amphitrite cirrata & - & - & - & - & - & ro & I4 \\
\hline Terebellides stroemii & - & - & - & - & - & I 2 & 67 \\
\hline Melinna palmata & - & - & - & - & - & - & 787 \\
\hline Lipobranchius jeffreysii & - & - & - & - & - & I & IO \\
\hline ceus & - & - & - & - & - & I4 & 25 \\
\hline
\end{tabular}

Table II. Distribution of Amphipods in Kames Bay

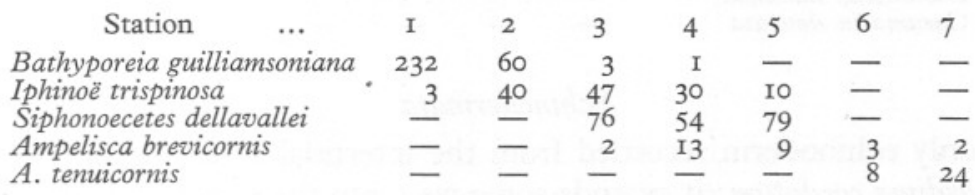

of about $30 \mathrm{~m}$. Only five species of amphipod are numerous below low-water mark (Table II). Bathyporeia guilliamsoniana appears in greatest numbers about low tide level and extends for a short way into the sublittoral. In deeper water Iphinoë trispinosa and Siphonoecetes dellavallei take its place. Ampelisca brevicornis (A. laevivata of Elmhirst) occurs in small numbers from station 3 to station 7 with a small maximum at stations 3 and 4 , while $A$. tenuicornis largely replaces it at stations 6 and 7 and extends into deeper water still.

\section{Mollusca}

Tellina tenuis is the dominant lamellibranch of the intertidal zone of Kames Bay (Watkin, I942); it extends a short way into the sublittoral zone and is then replaced by $T$. fabula (Table III). In deeper water still Abra alba becomes dominant; $A$. alba is both common and widely distributed in the Clyde area at greater depths than those studied here. The samples of Ensis ensis are probably unreliable: as a rule, only the tops of shells are taken by the mud 
bucket, and there is no means of telling how many individuals had retracted below the sampling depth altogether. The carnivorous gasteropod Philine aperta is moderately common at all stations below station 2 .

\begin{tabular}{|c|c|c|c|c|c|c|c|}
\hline Station & $\ldots$ & 2 & 3 & 4 & 5 & 6 & 7 \\
\hline Tellina tenuis & 1003 & 45 & 4 & - & - & - & - \\
\hline T. fabula & I5 & 98 & 147 & I59 & I 24 & - & - \\
\hline Spisula subtruncata & 12 & 69 & I3 & 4 & - & - & - \\
\hline Donax vittatus & 16 & 29 & & - & - & 一 & 一 \\
\hline Ensis ensis. & 5 & 20 & 8 & I3 & I2 & $-\overline{0}$ & - \\
\hline Venus gallina & 3 & 2 & 20 & 3 & 3 & I8 & - \\
\hline Cultellus pellucidus & & - & 2 & 6 & 25 & I6 & 4 \\
\hline Abra alba & - & 一 & - & 5 & I27 & 2 & 4 \\
\hline Dosinia lupinus & - & 一 & I & 4 & - & I9 & 83 \\
\hline Thyasira flexuosa & - & 一 & - & - & 2 & 54 & II \\
\hline Nucula nitida & - & - & 4 & I & I & 52 & 55 \\
\hline Philine aperta & I & 2 & 46 & 44 & I5 & 56 & 25 \\
\hline
\end{tabular}

\section{Table IV. Distribution of Echinoderms in Kames Bay}

\begin{tabular}{|c|c|c|c|c|c|c|}
\hline Station & I & 2 & 3 & 4 & 5 & 6 \\
\hline Echinocardium cordatum & 7 & 3 & $\mathrm{I} 2$ & 6 & 3 & - \\
\hline Astropecten irregularis & - & I & I & I & 3 & $\mathrm{I}$ \\
\hline $\begin{array}{l}\text { Ophiura affinis } \\
\text { O. albida }\end{array}$ & $\underline{I}$ & 二 & $\underline{2}$ & I & 8 & $\overline{43}$ \\
\hline $\begin{array}{l}\text { O. albida } \\
\text { Amphiura filiformis }\end{array}$ & - & - & - & - & - & 32 \\
\hline A. chiajei & - & 二 & 二 & 3 & 二 & $\overline{6}$ \\
\hline $\begin{array}{l}\text { Asterias rubens } \\
\text { Labidoplax thomsoni }\end{array}$ & 二 & - & $\bar{I}$ & 7 & I & - \\
\hline Cucumaria elongata & - & - & - & - & - & 4 \\
\hline
\end{tabular}

\section{Echinodermata}

The only echinoderm recorded from the intertidal zone of Kames Bay is Echinocardium cordatum; it extends some way into the sublittoral zone and is the only echinoid found in these comparatively shallow waters throughout the year. A marked zonation of ophiuroids exists, but only the fringe of it has been touched here. They extend into deeper water and from the trawl samples taken (vide infra) it is evident that the Robertson mud bucket is not ideal for collecting them. Amphiura filiformis is at its maximum numbers at station 7 and is replaced in deeper water by $A$. chiajei. Ophiura affinis is at a maximum at station 5 and is replaced by $O$. albida. In view of the unsatisfactory nature of the sampling, the figures given in Table IV must be regarded with some suspicion.

\section{The Superficial Fauna}

The superficial fauna and the bottom-feeding pelagic animals are not collected by the Robertson bucket. Some of these animals are present in large numbers and must play an important part in the economy of the bottom fauna as a whole. Some are more or less resident. Others, for example, certain pelagic crustaceans are known to migrate inshore from deeper waters at night 
and at high tide (Watkin, I94I). An intensive and extended investigation would therefore be needed to give a comprehensive picture of their distribution. This has not been attempted here, but a series of trawl samples made at each station in Kames Bay revealed that, at the shallowest stations at least, some of the commonest animals living on or in the substratum had been missed completely by the Robertson bucket (Table V).

\section{Table V. Animals taken in Trawl Samples at Each Station in Kames Bay}

Gammarus locusta Nototropis swammerdammi Pontocrates arenarius

$P$. norvegicus

Pseudocuma cercaria

Idotea baltica

I. viridis

I. granulosa

Schistomysis spiritus

Crangon vulgaris

Praunus flexuosus

Platynereis dumerillii

Asterias rubens

Ophiocomina nigra

\begin{tabular}{|c|c|c|c|c|c|c|c|c|c|}
\hline \multicolumn{2}{|c|}{ St. 1} & \multicolumn{2}{|c|}{ St. 2} & \multicolumn{2}{|c|}{ St. 3} & \multirow{2}{*}{$\begin{array}{l}\text { St. } 4 \\
\text { H.w. }\end{array}$} & \multirow{2}{*}{$\begin{array}{l}\text { St. } 5 \\
\text { H.w. }\end{array}$} & \multirow{2}{*}{$\begin{array}{l}\text { St. } 6 \\
\text { H.w. }\end{array}$} & \multirow{2}{*}{$\begin{array}{l}\text { St. } 7 \\
\text { H.w. }\end{array}$} \\
\hline w. & L.W. & w. & L.w. & H.w. & L.W. & & & & \\
\hline & 4566 & 2 & 98 & 2 & I & 5 & & - & \\
\hline & & 4 & 4 & - & & & & 3 & 2 \\
\hline $\mathrm{I}$ & & - & & 2 & 1 & - & - & - & \\
\hline 3 & & I & - & - & - & & - & - & \\
\hline 2 & & 2 & - & - & - & - & - & - & \\
\hline 136 & & - & - & - & - & - & $t^{*}$ & - & \\
\hline & & - & & - & - & - & - & - & \\
\hline I & & - & & I & - & & - & - & \\
\hline 89 & & I 72 & 07 & - & & - & - & - & \\
\hline $2 \mathrm{I}$ & & & & & & 1 & 2 & - & \\
\hline 6 & 2 & & & & I & - & - & - & \\
\hline & - & & & - & & - & 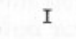 & - & \\
\hline $\bar{z}$ & - & - & $E$ & - & - & $\bar{z}$ & Z & I & \\
\hline
\end{tabular}

Crangon vulgaris, Schistomysis spiritus, Idotea baltica, Gammarus locusta, Nototropis swammerdammi and Pseudocuma cercaria are all plentiful at inshore stations though they are not represented at all in the mud-bucket samples. On the deeper stations the results of the trawl sampling do not alter materially the conclusions already drawn about the relative importance of the various members of the fauna, with two exceptions: (I) Ophiocomina nigra, which did not figure in the mud-bucket samples, is now seen to be present at station 7 . (2) Contrary to the mud-bucket findings (Table I), Platynereis dumerillii is probably more numerous at station 7 than station 6 , because of its association with matted vegetable material in the surface mud. The latter is about 50 times more plentiful at station 7 . For some reason this material is not normally taken by the bucket. And it is significant that of the total thirty-seven $P$. dumerillii from station 6 (Table I), thirty-one were in the sole bucket sample (from this or any other station) containing an appreciable quantity of the said material.

\section{Fauna of White Bay and a Comparison Between the Two Bays}

A similar series of mud-bucket samples was taken in White Bay on seven stations at the same depths as those of Kames Bay (see Fig. 2). The intertidal fauna of White Bay has never been studied. The sublittoral fauna is broadly 
the same as that of Kames Bay with some interesting differences, doubtless related to the greater exposure and consequent coarser substratum together with the absence of algal debris in White Bay.

\section{Polychaeta}

The only remarkable difference between the two bays is the virtual absence of Platynereis dumerillii. As we have already noted, this species is commonly associated with matted plant debris so that its absence is only to be expected. The other species have much the same distribution as in Kames Bay though the total numbers are somewhat smaller (see Table VI).

\section{Table VI. Distribution of Polychaetes in White Bay}

\begin{tabular}{|c|c|c|c|c|c|c|}
\hline Station & I & 2 & 3 & 4 & 5 & 6 \\
\hline Nephthys hombergii & I & 28 & 20 & 24 & I4 & 33 \\
\hline Spio filicornis & 2 & II & - & 5 & I & - \\
\hline Phyllodoce maculata & I8 & I9 & 2 & - & - & - \\
\hline $\begin{array}{l}\text { Sigalion mathildae } \\
\text { Owenia fusiformis }\end{array}$ & 二 & $\overline{3}$ & $\begin{array}{r}8 \\
27\end{array}$ & 93 & $\begin{array}{r}5 \\
24\end{array}$ & $\overline{22}$ \\
\hline $\begin{array}{l}\text { Owenia fusiformis } \\
\text { Glycera rouxii }\end{array}$ & - & - & $\begin{array}{r}27 \\
3\end{array}$ & $\begin{array}{r}94 \\
3\end{array}$ & 7 & $3 \mathrm{I}$ \\
\hline Goniada maculata & - & - & 2 & 2 & - & 50 \\
\hline Amphitrite cirrata & - & - & - & - & - & I9 \\
\hline Lumbrinereis hibernica & - & - & - & I & - & 36 \\
\hline $\begin{array}{l}\text { Scalibregma inflatum } \\
\text { Maldanidae }\end{array}$ & 二 & $\bar{z}$ & $\overline{6}$ & 二 & $\overline{28}$ & 37 \\
\hline Melinna palmata & - & - & - & I & 10 & $\begin{array}{r}75 \\
282\end{array}$ \\
\hline Notomastus latericeus & - & - & - & - & - & $\mathrm{I} 2$ \\
\hline
\end{tabular}

Some interesting differences appear in the crustacean fauna of White Bay (Table VII). Bathyporeia guilliamsoniana is much less common than in Kames Bay, but it appears in much the same part of the beach. Iphinoë trispinosa and Siphonocoetes dellavallei, both common in Kames Bay, are absent from White Bay. On the other hand, Ampelisca typica, which was not found in Kames Bay, is here present in moderate numbers having much the same range as $A$. brevicornis. These differences may be attributable either to the different nature of the substratum or to the lack of vegetable debris in White Bay.

\section{Mollusca}

Spisula subtruncata, Donax vittatus, Philine aperta and Nucula nitida are all common in Kames Bay, but are absent or virtually absent from White Bay. Abra alba, Cultellus pellucidus and Dosinia lupinus are present, but in reduced numbers. Natica alderi, which is absent from Kames Bay, is found in White Bay where it almost wholly replaces Philine aperta as the important carnivorous gasteropod. Species common to the two bays occupy the same position on the beach (see Table VIII). 


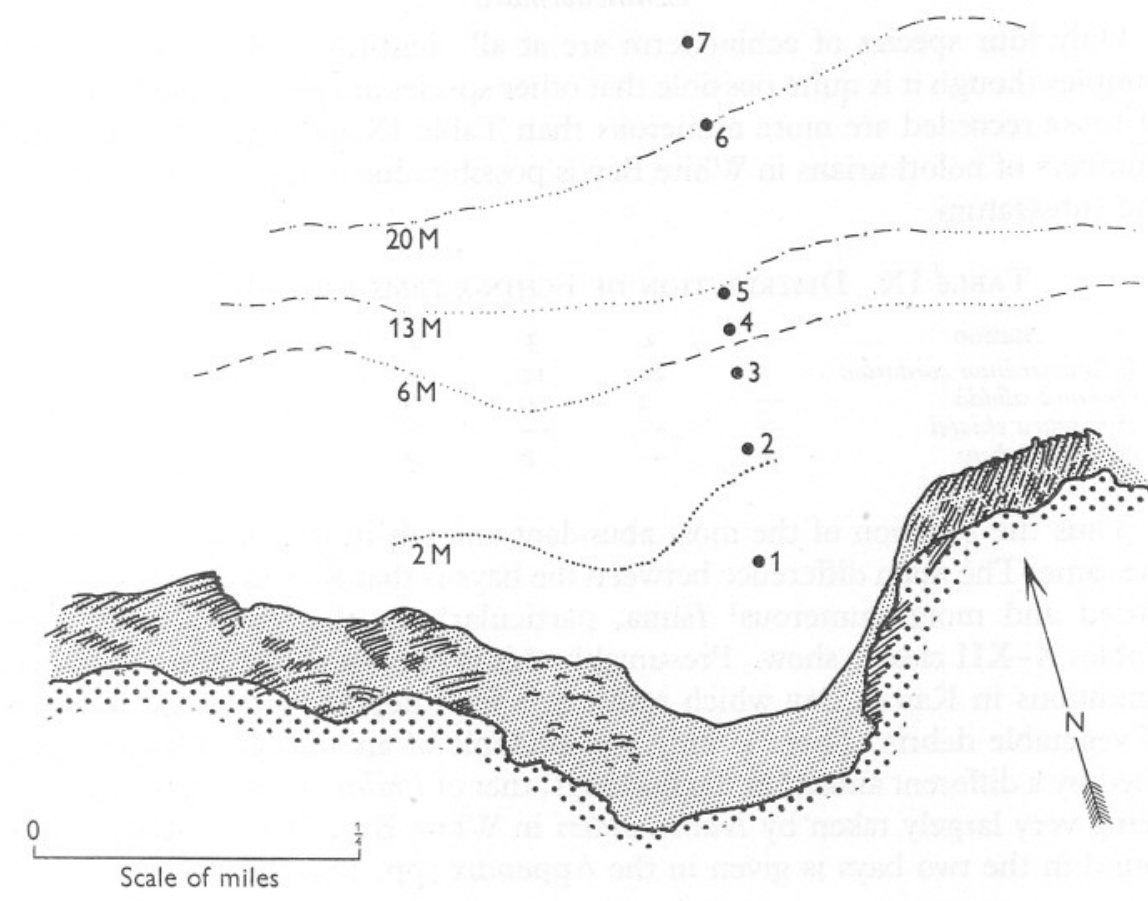

Fig. 2. White Bay, Isle of Cumbrae, showing the position of the stations at which samples were taken.

Table VII. Distribution of Amphipods In White Bay

\begin{tabular}{|c|c|c|c|c|c|c|}
\hline Station & I & 2 & 3 & 4 & 5 & 6 \\
\hline Bathyporeia guilliamsoniana & II & 35 & 7 & - & - & 一 \\
\hline $\begin{array}{l}\text { Ampelisca brevicornis } \\
\text { A. typica }\end{array}$ & - & 23 & $\begin{array}{l}27 \\
17\end{array}$ & 7 & 2 I & 二 \\
\hline A. tenuicornis & - & - & - & 3 & 2 & 6 \\
\hline
\end{tabular}

Table VIII. Distribution of Molluscs in White Bay

\begin{tabular}{|c|c|c|c|c|c|c|}
\hline Station & I & 2 & 3 & 4 & 5 & 6 \\
\hline Tellina tenuis & 826 & II 69 & 47 & 2 & 3 & 一 \\
\hline T. fabula & - & 83 & 358 & 216 & 44 & 一 \\
\hline Venus gallina & 28 & I9 & 3 & Io & 9 & - \\
\hline Ensis ensis & IO & 40 & I2 & 8 & - & 一 \\
\hline Abra alba & - & - & 7 & I & 4 & - \\
\hline Cultellus pellucidus & - & I & 8 & 2 & 2 & 2 \\
\hline Dosinia lupinus & 2 & 5 & II & 3 & I & II \\
\hline Natica ald̄eri & 7 & I2 & 8 & IO & 4 & 4 \\
\hline Thyasira flexuosa & - & - & - & 5 & I9 & 4 \\
\hline
\end{tabular}




\section{Echinodermata}

Only four species of echinoderm are at all plentiful in Robertson bucket samples though it is quite possible that other species are present and that some of those recorded are more numerous than Table IX indicates. The reduced numbers of holothurians in White Bay is possibly due to the coarser nature of the substratum.

\section{Table IX. Distribution of Echinoderms in White Bay}

\begin{tabular}{|c|c|c|c|c|c|c|}
\hline Station & I & 2 & 3 & 4 & 5 & 6 \\
\hline Echinocardium cordatum & 5 & 22 & II & 5 & - & - \\
\hline Ophiura albida & - & 2 & Io & 3 & 4 & 3 \\
\hline $\begin{array}{l}\text { Amphiura chiajei } \\
\text { Asterias rubens }\end{array}$ & $\bar{z}$ & $\bar{Z}$ & $\overline{8}$ & 5 & $\overline{0}$ & 3 \\
\hline
\end{tabular}

Thus the zonation of the most abundant animals in the two bays is much the same. The main difference between the bays is that Kames Bay has a more varied and more numerous ${ }^{1}$ fauna, particularly at the deeper stations as Tables X-XII clearly show. Presumably this is because of the more sheltered conditions in Kames Bay which result in a finer deposit with large amounts of vegetable debris. There is only one example of an ecological niche being filled by a different animal in the two bays, that of Philine aperta in Kames Bay being very largely taken by Natica alderi in White Bay. A full list of species found in the two bays is given in the Appendix (pp. I78-180).

Table X. Numbers of Species (S) and Individuals (I) Found in Ten Samples at each Station in Kames Bay

\begin{tabular}{|c|c|c|c|c|c|c|c|c|c|c|c|c|c|c|}
\hline \multirow[t]{2}{*}{ Station } & & I & \multicolumn{2}{|r|}{2} & \multicolumn{2}{|c|}{3} & \multicolumn{2}{|c|}{4} & \multicolumn{2}{|r|}{5} & \multicolumn{2}{|r|}{6} & \multicolumn{2}{|r|}{7} \\
\hline & $S$ & I & $S$ & I & S & I & S & ' & S & I & S & I & S & I \\
\hline Polychaeta & 7 & I87 & 3 & 109 & 8 & 93 & I3 & 208 & I3 & I95 & 32 & 1787 & $3 I$ & 1370 \\
\hline Amphipoda & 8 & 246 & 5 & 74 & IO & 125 & I0 & 108 & I0 & 120 & 6 & 24 & 3 & 29 \\
\hline Mollusca & 8 & 1006 & 9 & 232 & II & 218 & II & 219 & II & 303 & 20 & 230 & I3 & I85 \\
\hline Echinodermata & 2 & 8 & 2 & 3 & 4 & I6 & 6 & I9 & 6 & 23 & 7 & $8 I$ & 7 & 368 \\
\hline Totals* & 26 & I 483 & I9 & 418 & 35 & 455 & 45 & 559 & 42 & 645 & 70 & 2200 & 57 & 2026 \\
\hline
\end{tabular}

Table XI. Numbers of Species (S) and Individuals (I) Found in Ten Samples at each Station in White Bay

\begin{tabular}{|c|c|c|c|c|c|c|c|c|c|c|c|c|c|c|}
\hline \multirow[t]{2}{*}{ Station } & \multicolumn{2}{|c|}{ I } & \multicolumn{2}{|r|}{2} & \multicolumn{2}{|c|}{3} & \multicolumn{2}{|c|}{4} & \multicolumn{2}{|c|}{5} & \multicolumn{2}{|c|}{6} & \multicolumn{2}{|r|}{7} \\
\hline & $\mathrm{S}$ & I & $\mathrm{S}$ & I & S & I & S & I & S & I & S & I & S & I \\
\hline Polychaeta & II & 39 & Io & 73 & I7. & 88 & I8 & I68 & I3 & 95 & 27 & 766 & $2 \mathrm{I}$ & I043 \\
\hline Amphipoda & 7 & 33 & 6 & 63 & 4 & 53 & 3 & 23 & 4 & 29 & 4 & 12 & I & 3 \\
\hline Mollusca & 8 & 878 & II & I340 & 15 & 488 & Io & 257 & 9 & 87 & Io & 37 & 8 & I9 \\
\hline Echinodermata & I & 5 & 3 & 26 & 6 & 47 & 6 & I9 & 3 & I5 & 6 & I7 & 4 & $5 \mathrm{I}$ \\
\hline Totals* & 32 & 965 & $3 I$ & 1503 & 42 & 676 & $3^{8}$ & 472 & 30 & 227 & 48 & 833 & 38 & II 46 \\
\hline
\end{tabular}

${ }^{1}$ But see p. 162, regarding relative numbers of individuals of some species in the two bays. 
Table XiI. Comparison of the Fauna of Kames Bay and White Bay

\begin{tabular}{|c|c|c|c|c|}
\hline & \multicolumn{2}{|c|}{ Kames Bay } & \multicolumn{2}{|c|}{ White Bay } \\
\hline & Species & Individuals & Species & Individuals \\
\hline $\begin{array}{l}\text { Polychaeta } \\
\text { Amphipoda }\end{array}$ & $\begin{array}{l}47 \\
26\end{array}$ & $\begin{array}{r}3949 \\
726\end{array}$ & $\begin{array}{l}44 \\
\text { I4 }\end{array}$ & $\begin{array}{r}2272 \\
215\end{array}$ \\
\hline Mollusca & $3 \mathrm{I}$ & 2393 & 24 & 2108 \\
\hline Echinodermata & 12 & 518 & IO & I80 \\
\hline Totals* & I25 & 7786 & 102 & 5822 \\
\hline
\end{tabular}

* The total figures include a small number of animals not belonging to the four main groups.

There are practically no data on other bays with which to compare the present findings. A certain amount of collecting has been carried out in Ettrick Bay on the west side of Bute; the bay resembles Kames Bay more nearly than White Bay, but no sampling in shallow water has been possible there. So far as they go, the results from Ettrick Bay bear out the general tendencies found in Kames and White Bays.

\section{Distribution of Animals on the Sea Bed}

On examining samples from sublittoral deposits it is at once obvious that the density of some animals varies widely in successive sample units from the same station, while other animals appear to be more uniformly distributed. It is possible that the method of sampling might give a spurious impression of the distribution of some species. For instance, the mud bucket might bite deeper on one occasion than on another. But all methods of sampling the sublittoral fauna in use at present have this defect. Judging from the uniform performance of the Robertson bucket at depths where it is visible, there is strong reason for thinking that ten buckets would not vary much in character among themselves at any one station. A more important consideration is that samples of ten units are too small for certain types of statistical treatment.

In considering the nature of the distribution of organisms over an area, Fisher's 'coefficient of dispersion' may be used. It was introduced first in plant ecology, e.g. by Clapham (1936) and Blackman (1942), and later in terrestrial and marine ecology, e.g. by Salt \& Hollick (I946), Holme (I950) and Barnes \& Marshall (195I). The coefficient of dispersion is given by

$$
\Sigma(x-\bar{x})^{2} / \bar{x}(n-\mathrm{I}) \text {, }
$$

where $\Sigma(x-\bar{x})^{2}$ is the sum of squares of the deviations of individual units $(x)$ from the mean $(\bar{x})$ of all the units $(n)$ comprising the sample. The coefficient leads to unity when the population is randomly distributed, is less than one if the population is over-dispersed (i.e. more or less evenly distributed) and greater than one if it is underdispersed (i.e. more or less aggregated). The significance of the departure from unity is tested by

$$
\mathrm{I} \pm 2 \times \sqrt{\left[2 n /(n-\mathrm{I})^{2}\right]},
$$


where, again, $n$ is the number of units in the sample. In the present bucket samples, $n=\mathrm{IO}$ and the limits of the coefficient for random distribution are therefore I.9938 and 0.0062 . A coefficient greater than I.9938 may then be taken as significant evidence of aggregation. But obviously, with the lower limit at 0.0062 the coefficient can not be expected to distinguish between random and over-dispersed distribution in samples of ro units. The sample size need only have been doubled to permit the distinction, although, of course, the larger the sample the better, as the following tabulation shows:

$\begin{array}{cc}\text { Sample size } & \begin{array}{c}\text { Limits of the coefficient } \\ \text { of dispersion for } \\ \text { random distribution }\end{array} \\ \text { I0 } & 0.0062-\mathrm{I} \cdot 9938 \\ 20 & 0.3342-\mathrm{I} \cdot 6658 \\ 50 & 0.5918-\mathrm{I} \cdot 4082 \\ \text { 100 } & 0.7142-\mathrm{I} \cdot 2858\end{array}$

Departure from randomness may of course be tested by fitting a Poisson distribution from the sample mean and then applying the $\chi^{2}$ test with $n-2$ degrees of freedom. And Blackman warns that "when the coefficient of dispersion value is not significantly different from unity the $\chi^{2}$ test should still be applied since the coefficient of dispersion test, although sensitive as regards aggregation, will not detect certain types of skew distribution'. He gives a field example (a sample of roo units) where the coefficient obtained though greater than unity is not significantly different from it, yet the evidence of the $\chi^{2}$ test is that the distribution is not random. Thomson (I952) confirms Blackman. Unfortunately, with a sample size of only io units, the direct calculation of $\chi^{2}$ for a fitted Poisson provides little or no useful information.

Some writers have pointed out that the quantity

$$
\Sigma(x-\bar{x})^{2} / \bar{x},
$$

known as the 'index of dispersion', is approximately distributed as $\chi^{2}$ with $n-\mathrm{I}$ degrees of freedom if the data come from a Poisson population. 'For $\bar{x} \geqslant 5$ the $\chi^{2}$ approximation... is highly satisfactory even for $n$, the number of observations, as small as 5 , and is fairly accurate for $\bar{x}<5$, although it will tend to give too few significant results' (Bateman, 1950). With $n=10$, the $P=0.05$ value of $\chi^{2}$ is 16.919. And since the index of dispersion is $(n-\mathrm{I})$ times the coefficient of dispersion, this $\chi^{2}$ value is equivalent to a coefficient of $\mathrm{I} 6 \cdot 9 \mathrm{I} 9 / 9=\mathrm{I} \cdot 8799$ which is practically the same as the limit $\mathrm{I} \cdot 9938$ given above. But while a coefficient $>\mathrm{I} \cdot 9938$ is significant evidence of aggregation, an index $\equiv \chi^{2}>$ I6.919 is merely significant evidence of non-randomness, i.e. the index apparently can not distinguish between aggregation and overdispersion.

Three other measures of dispersion are discussed by Thomson (I952) but none are appropriate for the present data. We must therefore confine ourselves to employing the coefficient of dispersion alone in an attempt to 
distinguish between aggregated and non-aggregated species, bearing in mind that animals falling into the latter group may be either randomly distributed, or distributed in a skew but non-Poisson fashion, or overdispersed.

At each station the coefficient of dispersion has been calculated for each species occurring in the ten buckets. Altogether, 459 coefficients are available from the two bays and they range from 0.2593 up to $69^{\circ} 99$. Since only $19.4 \%$ of coefficients are above the significance limit I.9938, it seems that nonaggregated distribution (probably chiefly random) is the general rule in the community dwelling on and in the upper layer of the sea bed. As will be seen below, this conclusion requires testing with different sizes of bucket (sample unit).

Aggregation is, of course, out of the question if there is only one individual of a species among ten buckets. But with $n=10$, the coefficient of dispersion is greater than 1.9938 whenever there are two or more individuals in one bucket and none at all in the remaining nine buckets. Hence significant evidence of aggregation can be obtained from densities of 0.2 per bucket and upwards. Table XIII gives the complete list of species showing evidence of aggregation in at least one sample of ten buckets. In general, the samples of these species do not show consistent evidence of aggregation until the mean per bucket is greater than about I0.0. Above a mean of I0.0, $94 \cdot \mathrm{I} \%$ of samples have a coefficient indicating aggregation. Below that mean level, the percentage dwindles in a smooth curve until at means of $0.2-0.9$ per bucket it is only $26 \%$. This is to be expected from the well-known empirical finding that the smaller the mean for a particular sample unit, the more nearly will a contagious or aggregated distribution conform to the Poisson Law: variance $=$ mean. An obvious corollary is that the demonstration of aggregation will depend to some extent on the dimensions of the sample unit. Thus evidence of aggregation may disappear altogether if a smaller unit (e.g. bucket or quadrat) is used, simply because the mean per unit is reduced. Evans (I952) confirmed this by experimenting (on paper) with different unit (quadrat) sizes on the mapped data from a field in which the plants had been 'completely enumerated'. And he makes the sound point that dispersion should be investigated with more than one size of sample unit.

Partly from the nature of the data and partly from the sketchiness of biological and ecological knowledge at the present time, there is little of value to be concluded from the data on individual species showing some evidence of aggregation (Table XIII) or none at all (Table XIV).

Polychaeta. Ten errant and nine sedentary species of Polychaeta show some evidence of aggregation while six errant and fourteen sedentary species do not. That is $62.5 \%$ of errant species but only $39.1 \%$ of sedentary species show evidence of aggregation in the two bays. This difference of proportion is significant, $\chi^{2}=4.976, P=0.03$. Hence errant polychaetes tend more to be aggregated than sedentary polychaetes. 


\section{Table XIII. Species showing Statistical Evidence of Aggregation IN AT LEAST ONE SAMPLE*}

(Samples classified as aggregated (A, i.e. coefficient of dispersion $>I \cdot 9938)$ and non-aggregated (non-A, i.e. coefficient of dispersion $<\mathrm{I} \cdot 9938$ ) at different mean levels greater than $0 . \mathrm{I}$ individual per bucket.)

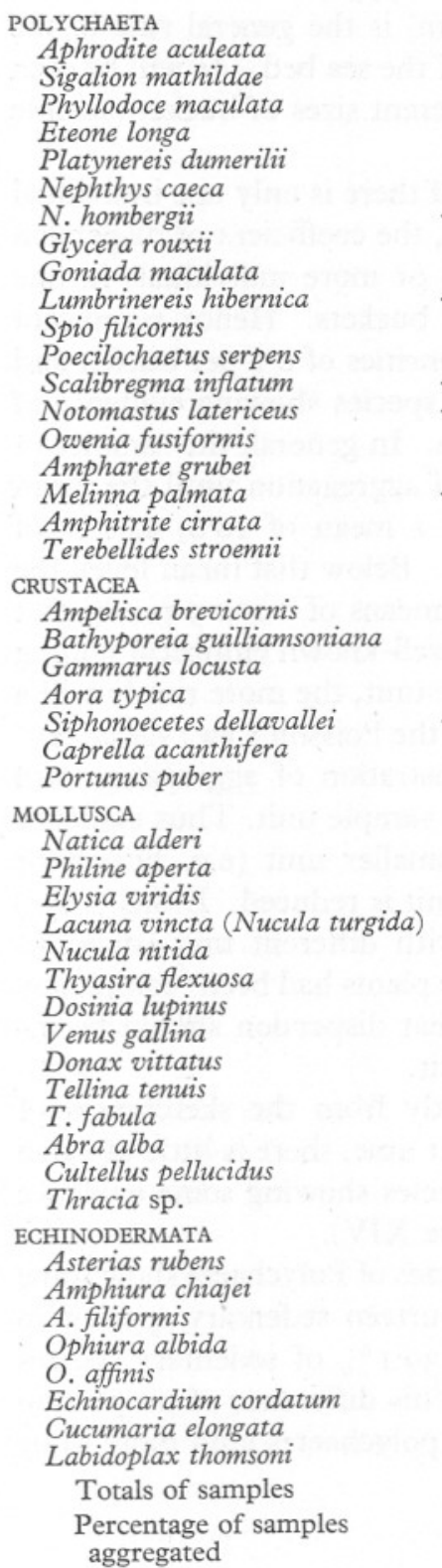

\begin{tabular}{|c|c|c|c|c|}
\hline \multicolumn{5}{|c|}{ Mean individuals per bucket } \\
\hline $0.2-0.9$ & $\mathrm{I} \cdot \mathrm{O}-\mathrm{I} \cdot 9$ & $2.0-3.9$ & $4.0-9 \cdot 9$ & $>10.0$ \\
\hline A $\begin{array}{c}\text { Non- } \\
\mathrm{A}\end{array}$ & A $\quad \begin{array}{c}\text { Non- } \\
\text { A }\end{array}$ & A $\begin{array}{r}\text { Nor } \\
\text { A }\end{array}$ & $A^{\mathrm{No}}$ & A \\
\hline
\end{tabular}


Table XIV. Species Showing no Sign of Aggregation in any Sample WITH MEAN GREATER THAN O.I INDIVIDUAL PER BUCKET

\begin{tabular}{|c|c|c|c|c|c|}
\hline . & $\begin{array}{l}\text { No, of } \\
\text { samples of } \\
\text { ro buckets }\end{array}$ & $\begin{array}{l}\text { Range of } \\
\text { means }\end{array}$ & & $\begin{array}{l}\text { No. of } \\
\text { samples of } \\
\text { ro buckets }\end{array}$ & $\begin{array}{l}\text { Range of } \\
\text { means }\end{array}$ \\
\hline TURBELLARIA & & & Urothoë marina & $\mathbf{I}$ & 0.3 \\
\hline Cryptocelis alba & 4 & $0.2-1 \cdot 0$ & U. brevicornis & I & 0.2 \\
\hline POLYCHAETA, & & & Phoxocephalus holbölli & I & \\
\hline Gattyana cirrosa & 3 & $0.4-0.8$ & Pontocrates arenarius & 2 & $0.7,1.0$ \\
\hline Harmothoë lunulata & I & 0.4 & Nototropis guttatus & I & 0.2 \\
\hline Sthenelais limicola & 4 & $0.2-2.0$ & Maera othonis & I & 0.4 \\
\hline Phyllodoce kosteriensis & $\vec{I}$ & 0.3 & Dexamine spinosa & I & 0.4 \\
\hline Eulalia sanguinea & I & 0.7 & fassa ocia & I & 0.5 \\
\hline Nephthys longosetosa & 3 & $0.2-2.8$ & Eupagurus bernhardus & I & 0.3 \\
\hline $\begin{array}{l}\text { Scoloplos armiger } \\
\text { Laonice cirrata }\end{array}$ & 4 & $0.2-0.4$ & MOLLUSCA & & \\
\hline $\begin{array}{l}\text { Laonice cirrata } \\
\text { Spiophanes bombyx }\end{array}$ & 2 & $0.2,0.3$ & Chiton sp. & 2 & $0.3,0.6$ \\
\hline $\begin{array}{l}\text { Spiophanes bomby } x \\
\text { Pygospio elegans }\end{array}$ & $\begin{array}{l}1 \\
2\end{array}$ & $\begin{array}{l}0.3 \\
0.2\end{array}$ & Aporrhais pes-pelecani & 3 & $0.3-0.5$ \\
\hline Magelona cincta & 2 & $\begin{array}{c}0.2 \\
0.4,0.5\end{array}$ & Nassarius reticulatus & I & 0.2 \\
\hline Cirratulus filiformis & 3 & $0.2-0.9$ & Haedropleura septangularis & I & 0.4 \\
\hline Stylarioides plumosa & 3 & $0 \cdot 3-1 \cdot 5$ & Nucula tenuis & 4 & $0.2-0.6$ \\
\hline Lipobranchius jeffreysii & $\mathrm{I}$ & 0.2 & Nuculana minuta & I & 0.3 \\
\hline Ammotrypane aulogaster & 2 & 0.2 & Kellia suborbicularis & 2 & $0.3,0.6$ \\
\hline Pectinaria auricoma & 3 & $0.2-0.6$ & Montacuta ferruginosa & 3 & $0.2-0.5$ \\
\hline Lanice conchilega & $\vec{I}$ & 0.3 & Venerupis rhomboides & I & 0.2 \\
\hline Pista cristata & I & 0.5 & Gari fervensis & I & 0.3 \\
\hline Trichobranchius glacialis & 4 & $0.4-I \cdot 3$ & Ensis ensis & 9 & $0.5-4.0$ \\
\hline Euchone rosea & I & 0.2 & Spisula subtruncata ${ }^{\star}$ & 5 & $0.2-5 \cdot 5$ \\
\hline CRUSTACEA & & & $\begin{array}{l}\text { Mya sp. } \\
\text { Corbula gibba }\end{array}$ & $\begin{array}{l}1 \\
2\end{array}$ & $0.2,0.5$ \\
\hline Iphinoë trispinosa & 5 & $0 \cdot 3-4 \cdot 4$ & ECHINODERMATA & & \\
\hline Diastylis laevis & I & 0.2 & Astropecten irregularis & $\mathbf{I}$ & 0.3 \\
\hline Hippomedon denticulatus & 2 & $0.7,0.8$ & Acrocnida brachiata & I & 0.2 \\
\hline $\begin{array}{l}\text { Tryphosites longipes } \\
\text { Ampelisca temuicornis }\end{array}$ & $\begin{array}{l}I \\
6\end{array}$ & $\begin{array}{c}0.3 \\
0.2-2.4\end{array}$ & Holothurian sp. & 2 & $0.4,1 \cdot 5$ \\
\hline $\begin{array}{l}\text { Ampelisca tenutcormis } \\
\text { A. typica }\end{array}$ & 3 & $\begin{array}{l}0.2-2.4 \\
0.5-1 \cdot 7\end{array}$ & \multirow{3}{*}{\multicolumn{3}{|c|}{$\begin{array}{l}\text { * At the second highest mean, } \mathrm{I} \cdot 0, \text { Spisula was not } \\
\text { aggregated }(\mathrm{I} \cdot 7778) \text { but at the highest mean, } 5 \cdot 5 \text {, it } \\
\text { was very nearly to be regarded so }(\mathrm{I} \cdot 9900)\end{array}$}} \\
\hline $\begin{array}{l}\text { Bathyporeia elegans } \\
\text { Haustorius arenarius }\end{array}$ & 2 & $0.2,0.3$ & & & \\
\hline & & & & & \\
\hline
\end{tabular}

Crustacea. The writers see nothing to add to what the tables say.

Mollusca. According to Holme (I950), at lower densities Tellina tenuis is over-dispersed rather than randomly distributed or aggregated. This is not the case in the present work since samples with means of $0.2,0.2$ and 0.3 per bucket gave coefficients of dispersion equal to $2 \cdot 0000,0.8889$ and I.5I85 respectively; and samples with means greater than 2.0 per bucket invariably had a coefficient of dispersion denoting aggregation. The disagreement with Holme is probably explained by sample size.

Echinodermata. It is well known that Ophiuroids tend to aggregate, and the present results, with two species of Ophiura and two of Amphiura, confirm this.

In some cases large local variations in population density may reflect the effects of local differences in the nature of the substratum on the settlement of larvae or their survival after settlement. For this to be the main cause of the marked patchiness of distribution shown by species in Table XIII it must be assumed that the sea bed is a veritable mosaic in which one square yard of the bottom may differ markedly from the next. This is hardly credible. One imagines uniform conditions existing on a sandy or muddy bottom, and certainly the bucket samples suggest uniformity of conditions within each station. The larger variance/mean ratio (coefficient of dispersion) of the species in Table XIII arises more likely from living habits which lead to aggregation of individuals. 
Without knowing more about their life histories and habits, it is difficult or impossible to say what might cause aggregation in the individual species listed in Table XIII. Species lacking a dispersal phase and which are fairly sedentary in adult life would naturally tend to collect into family aggregations and one consequence of this in the speciation of polychaetes has already been suggested (Clark, I952). However, this can not explain aggregations in two of the amphipod species which are active swimmers, leave the sand for breeding and appear in the plankton at night (Watkin, I94I). In these cases the formation of aggregations must be an active process, as it may also be in the case of the polychaete Goniada maculata which has a pelagic larva and which is probably an active swimmer in the adult stage. Again, none of the molluscs in Table XIII is known to have lost its dispersive pelagic larval phase; unless differential mortality takes place after the molluscan larvae have settled on the substratum, active aggregation must be assumed. No doubt the factors leading to the formation of aggregations differ not only from group to group but also from species to species. A well-known instance of active aggregation occurs among the Ophiuroidea. Allee (1927) has shown that ophiuroids disperse when living among Zostera and can be made to disperse in the laboratory when provided with artificial vegetation in the form of glass rods. Yet living (as they commonly do) on a fairly bare substratum, they form aggregations unless, apparently, the density is too low. Such aggregations on the sea bed have been photographed by Vevers (1951, I952).

This work was carried out at the Marine Station, Millport. The authors are indebted to Dr R. B. Pike for discussions and information relating to the faunistic work. One of the authors (A. M.) worked on a Carnegie Scholarship 1938-39, the other (R. B. C.) was aided by a grant from The Browne Research Fund of The Royal Society during the summer of 1950.

\section{SUMMARY}

A preliminary study has been made of the composition and distribution of the macrofauna living on and in the substratum from low tide level to a depth of about $30 \mathrm{~m}$ in Kames Bay and White Bay on the Isle of Cumbrae in the Firth of Clyde. Samples were taken mainly by means of the Robertson mud bucket. A small amount of trawling was done as a check on results for animals dwelling at the surface of the substratum.

The main physical differences between the two bays are: (I) Kames Bay is more sheltered and has a finer deposit of sand or mud at each station with fewer stones and shells than White Bay; (2) in Kames Bay, a substantial quantity of vegetable debris is washed backwards and forwards with the tide in the upper part of the sublittoral zone and there is a large amount of decomposing organic material mixed with the superficial mud at a depth of about $30 \mathrm{~m}$; both these circumstances are practically absent in White Bay. 
Full lists are given of the macro-species occurring on and in the sea bed from low-water mark out to $30 \mathrm{~m}$ in the two bays. White Bay is somewhat poorer in variety of species and density of individuals than Kames Bay. The only other really important difference is that Philine aperta, abundant in Kames Bay, is replaced almost wholly in White Bay by Natica alderi as the carnivorous gasteropod.

The distribution of the intertidal fauna of Kames Bay, but not of White Bay, has been extensively studied in the past. The present results therefore extend the picture of animal zonation from high-water mark out to $30 \mathrm{~m}$ depth in Kames Bay.

When aggregation occurs, the possibility of its demonstration by means of the coefficient of dispersion depends to some extent on the size of the sample unit. With the Robertson Mud Bucket as the unit, the array of coefficients (calculated from all samples of all species occurring) suggests that nonaggregated distribution (probably chiefly random) is the general rule in the bottom community of the sublittoral. Of some I50 species comprising the invertebrate macrofauna, forty-eight showed significant evidence of aggregation in at least one sample; but the evidence is consistent over all available samples in less than half a dozen species.

\section{REFERENCES}

ALLEE, W. C., I927. Studies in animal aggregations: some physiological effects of aggregations in the brittle starfish Ophioderma brevispina. F. exp. Zool., Vol. 48, pp. $475-95$.

BARNES, H. \& MARSHALl, S. M., I95I. On the variability of replicate plankton samples and some applications of 'contagious' series to the statistical distribution of catches over restricted periods. F. Mar. biol. Ass. U.K., Vol. 30, pp. 233-63.

BATEMAN, G. I., I950. The power of the $\chi^{2}$ index of dispersion test when Neyman's contagious distribution is the alternate hypothesis. Biometrika, Vol. 37, pp. 59-63.

BLACKMAN, G. E., I 942 . Statistical and ecological studies in the distribution of species in plant communities. I. Dispersion as a factor in the study of changes in plant populations. Ann. Bot., Lond., N.S., Vol. 6, pp. 35I-70.

Clapham, A. R., I936. Over-dispersion in grassland communities and the use of statistical methods in plant ecology. F. Ecol., Vol. 24, pp. 232-51.

Clark, R. B., I952. Speciation of polychaetes in the Clyde Sea Area. Nature, Lond., Vol. 169, p. 975 .

ELMHIRST, R., I93I. Studies in the Scottish marine fauna. The Crustacea of the sandy and muddy areas of the tidal zone. Proc. roy. Soc. Edinb., Vol. 51, pp. I69-75.

Evans, F. C., I952. The influence of size of quadrat on the distributional patterns of plant populations. Contr. Lab. Vertebr. Biol. Univ. Mich., No. 54, pp. I-I5.

Holme, N. A., I950. Population-dispersion in Tellina tenuis da Costa. F. Mar. biol. Ass. U.K., Vol. 29, pp. 267-80.

SALT, G. \& Hollick, F. S. J., I946. Studies in wireworm populations. II. Spatial distribution. F. exp. Biol., Vol. 23, pp. I-46.

STEPHEN, A. C., I928. Notes on the quantitative distribution of molluscs and polychaetes in certain intertidal areas on the Scottish coast. Proc. R. phys. Soc. Edinb., Vol. 21, pp. 205-I6. 
Stephen, A. C. I929. Studies in the Scottish marine fauna: the fauna of sandy and muddy areas in the tidal zone. Trans. roy. Soc. Edinb., Vol. 56, pp. 29I-306.

- 1930. Studies in the Scottish marine fauna: additional observations on the fauna of the sandy and muddy areas of the tidal zone. Trans. roy. Soc. Edinb., Vol. 56, pp. $52 \mathrm{I}-35$.

Thомson, G. W., 1952. Measures of plant aggregation based on contagious distribution. Contr. Lab. Vertebr. Biol., Univ. Mich., No. 53, pp. I-17.

Vevers, H. G., I951. Photography of the sea floor. F. Mar. biol. Ass. U.K., Vol. 30, pp. IOI-II.

- I952. A photographic survey of certain areas of sea floor near Plymouth. F. Mar. biol. Ass. U.K., Vol. 31, pp. 215-21.

WatKIN, E. E., I94I. Observations on the night tidal migrant Crustacea of Kames Bay. F. Mar. biol. Ass. U.K., Vol. 25, pp. 81-96.

- I942. The macrofauna of the intertidal sand of Kames Bay, Millport, Buteshire. Trans. roy. Soc. Edinb., Vol. 60, pp. 543-61.

\section{APPENDIX}

Species taken in the Robertson Mud-Bucket Samples in Kames Bay and White Bay.

( $\mathrm{K}$, recorded from Kames Bay only. W, recorded from White Bay only.)

\section{TURBELLARIA}

$\mathrm{K}$ Cryptocelis alba (Lang)

$$
\text { Lineus spp. } \text { NEMERTINEA }
$$

Aphrodite aculeata $\mathrm{L}$.

$\mathrm{K}$ Lepidonotus squamatus (L.)

Gattyana cirrosa (Pallas)

K Harmothoë imbricata (L.)

W H. longisetis (Grube)

$H$. lunulata (Delle Chiaje)

Sigalion mathildae Audouin \& MilneEdwards

Sthenelais limicola (Ehlers)

Phyllodoce maculata (L.)

K P. kosteriensis (Malmgren) Phyllodoce sp.

$\mathrm{K}$ Eulalia sanguinea (Oersted) Eulalia sp.

Eteone longa (Fabricius)

$\mathrm{K}$ E. lactea Claparède

$\mathrm{K}$ Eteone $\mathrm{sp}$.

$\mathrm{K}$ Nereis longissima (Johnston) Platynereis dumerilii (Audouin \& MilneEdwards)

W Nephthys caeca Fabricius N. hombergii Audouin \& Milne-Edwards

W N. longosetosa Oersted Glycera rouxii Audouin \& Milne-Edwards Goniada maculata Oersted Lumbrinereis hibernica McIntosh Scoloplos armiger (O. F. Müller) Laonice cirrata (Sars) Spiophanes bombyx (Claparède) Spio filicornis (O. F. Müller)
W Pygospio elegans Claparède

K Magelona papillicornis F. Müller $M$. cincta Ehlers

W Poecilochaetus serpens Allen Cirratulus filiformis Keferstein

$\mathrm{K}$ Chaetozone setosa Malmgren Stylarioides plumosa (O. F. Müller) Scalibregma inflatum Rathke Lipobranchius jeffreysii (McIntosh) Ammotrypane aulogaster Rathke Notomastus latericeus Sars Maldanidae

$\mathrm{K}$ Rhodine $\mathrm{sp}$.

$\mathrm{K}$ Axiothella sp. Owenia fusiformis Delle Chiaje

W Pectinaria koreni Malmgren $P$. auricoma (Müller)

$\mathrm{K}$ Ampharete grubei Malmgren Anobothrus gracilis (Malmgren)

$\mathrm{K}$ Amphicteis gunneri (Sars) Melinna palmata Grube Amphitrite cirrata (O. F. Müller)

W Lanice conchilega (Pallas) Pista cristata (Müller) Trichobranchius glacialis Malmgren Terebellides stroemii Sars

W Euchone rosea Langerhans

Cumacea

CRUSTACEA

$\mathrm{K}$ Iphinoë trispinosa (Goodsir)

W Lamprops fasciata G. O. Sars

$\mathrm{K}$ Dyastilis laevis Norman

Isopoda

W Cirolana sp.

$\mathrm{K}$ Idotea granulosa Rathke 
Amphipoda

$\mathrm{K}$ Acidostoma laticorne O. Sars Hippomedon denticulatus (Bate)

$\mathrm{K}$ Tryphosites longipes (Bate \& Westwood) Ampelisca brevicornis (A. Costa) A. tenuicornis Lilljeborg

W A. typica (Bate)

$\mathrm{K}$ Ampelisca sp. Bathyporeia guilliamsoniana (Bate)

$\mathrm{K}$ B. elegans

W Bathyporeia sp.

W Haustorius arenarius (Slabber)

W Urothoë marina (Bate)

U. brevicornis Bate

$\mathrm{K} U$. elegans Bate

W Phoxocephalus holbölli (Krøyer)

W Leucothoë incisa D. Robertson

K Perioculoides longimanus (Bate \& Westwood)

Pontocrates arenarius (Bate)

K Nototropis guttatus (A. Costa)

W N. swammerdammi (Milne-Edwards)

$\mathrm{K}$ Eusiris longipes Boeck

K Melita obtusata Montagu

W Meara othonis (Milne-Edwards)

$\mathrm{K}$ Gammarus locusta (L.)

$\mathrm{K}$ Dexamine spinosa (Montagu)

$\mathrm{K}$ Orchestia sp.

$\mathrm{K}$ Hyale nilsonii (Rathke)

$\mathrm{K}$ Aora typica Krøyer

$\mathrm{K}$ Fassa falcata (Montagu)

$\mathrm{K}$ F. ocia (Bates)

$\mathrm{K}$ Siphonoecetes dellavallei Stebbing

$\mathrm{K}$ Caprella acanthifera Leach

Decapoda

W Crangon vulgaris (L.) Eupagurus bernhardus (L.)

W Porcellana longicornis Pennant

$\mathrm{K}$ Ebalia cranchi Leach

$\mathrm{K}$ Corystes cassivelaunus (Pennant) Portunus puber (L.)

$\mathrm{K} P$. holsatus Fabricius

Placophora

MOLLUSCA

W Chiton sp.

Gastropoda

W Gibbula cineraria (L.)

$\mathrm{K}$ Turritella communis Risso

W Capulus ungaricus (L.) Aporrhais pes-pelicani da Costa

W Natica alderi Forbes

$\mathrm{K}$ Nassarius reticulatus (L.)
$\mathrm{K}$ Haedropleura septangularis (Montagu)

$\mathrm{K}$ Haedropleura sp.

$\mathrm{K}$ Cylichna cylindracea (Pennant)

Philine aperta Ascanius

Neptunea antiqua (L.)

Lamellibranchia

Nucula turgida Leckenby \& Marshall

$N$. tenuis (Montagu)

Nuculana minuta (Müller)

Thyasira flexuosa (Montagu)

$\mathrm{K}$ Kellia suborbicularis (Montagu)

Montacuta ferruginosa (Montagu)

$\mathrm{K}$ Cardium echinatum L. Dosina lupinus (Montagu)

$\mathrm{K}$ Venus casina $\mathrm{L}$. V. striatula (da Costa)

W Venerupis (Tapes) rhomboides (Pennant)

$\mathrm{K}$ Donax vittatus (da Costa)

Tellina tenuis da Costa

T. fabula Gmelin

Abra alba (Wood)

$\mathrm{K}$ Gari fervensis (Gmelin)

Cultellus pellucidus (Pennant)

Ensis ensis (L.)

Spisula subtruncata (da Costa)

W Mya sp.

Corbula gibba (Olivi)

W Cochlodesma praetenue (Montagu)

K Thracia sp.

$\mathrm{K}$ Cuspidaria cuspidata Brown.

Asteroidea

ECHINODERMATA

$\mathrm{K}$ Astropecten irregularis (Pennant) Asterias rubens L.

Ophiuroidea

Amphiura chiajei Forbes

A. filiformis (O. F. Müller)

Acrocnida brachiata (Montagu)

$\mathrm{K}$ Ophiura texturata Lamarck

$O$. albida Forbes

$\mathrm{K} O$. affinis Lütken

Echinoidea

W Echinus esculentus L.

Echinocardium cordatum (Pennant)

Holothuroidea

Cucumaria elongata Düben \& Koren

Labidoplax thomsoni (Herapath)

PISCES

$\mathrm{K}$ Ammodytes tobianus $\mathrm{L}$.

$\mathrm{K}$ Lepadogaster bimaculatus (Donovan) 


\section{Additional Species taken by Trawl in Kames Bay}

(W, species known also to occur in White Bay)

Actinea equina $\mathrm{L}$. COELENTERATA

\section{POLYCHAETA}

Eulalia fucescens St Joseph Platynereis dumerilii (Audouin \& MilneEdwards)

Cumacea

$$
\text { CRUSTACEA }
$$

Pseudocuma longicornis (Bate)

Isopoda

Idotea baltica (Pallas)

I. pelagica Leach

I. viridis (Slabber)

I. emarginata (Fabricius)

I. linearis (Pennant)

I. gramulosa Rathke

Faera marina (Fabricius)

Amphipoda

Orchomene humilis (A. Costa)

Bathyporeia sp.

Pontocrates arenarius (Bate)

$P$. norvegicus Boeck

Monoculodes sp.

W Nototropis swammerdammi (Milne-

Edwards)

Megaluropus agilis Hoek

Melita gladiosa Bate(?)

Gammarus locusta (L.)

Microdeutopus sp.

Amphithoë rubicata (Montagu)

Caprella sp.

Mysidacea

Erythrops elegans (G. O. Sars)

Mysidopsis augusta G. O. Sars

M. gibbosa G. O. Sars

Schistomysis spiritus (Norman)

S. ornata (G. O. Sars)

Praunus flexuosus (Müller)

Acanthomysis longicornis (Milne-Edwards)

Decapoda

Pandalus montagui Leach

Pandalina brevirostris (Rathke)
Hippolyte varians Leach

Spirontocaris cranchi (Leach)

S. pusiola (Krøyer)

Leander serratus (Pennant)

W Crangon vulgaris (L.)

Philocheras bispinosus (Hailstone \& Westwood)

P. trispinosus (Hailstone)

Eupagurus prideauxii Leach

Portunus corrugatus (Pennant)

Macropodia rostrata L.

Gastropoda

MOLLUSCA

W Gibbula cineraria L. (?)

Scaphander lignarius (L.)

Aplysia punctata Cuvier

Pleurobranchus membranaceus (Montagu)

Acanthodoris pilosa (Abildgaard)

Lamellibranchia

Chlamys varia (L.)

Crinoidea

ECHINODERMATA

Antedon bifida (Pennant)

$A$. petasus (Düben \& Koren)

Asteroidea

Asterias rubens L.

Ophiuroidea

Ophiothrix fragilis (Abildgaard)

Ophiocomina nigra (Abildgaard)

Ophiopholis aculeata (L.)

Echinoidea

W Echinus esculentus L.

Raia clavata L.

PISCES

Nerophis lumbriciformis (Pennant)

Syngnathus acus L.

Centronotus gunnellus (L.)

Callionymus maculatus (Rafinesque)

Gobius minutus Pallas

Pleuronectes limanda L.

Solea lutea (Risso). 